\title{
Executives' Environmental Awareness and Eco-Innovation: An Attention-Based View
}

\author{
Yongbo Sun and Hong Sun *(i) \\ Business School, Beijing Technology and Business University, Beijing 100048, China; sunyb@th.btbu.edu.cn \\ * Correspondence: sunhong97825@163.com; Tel.: +86-1371-891-5601
}

check for

updates

Citation: Sun, Y.; Sun, H. Executives' Environmental Awareness and Eco-Innovation: An Attention-Based View. Sustainability 2021, 13, 4421. https://doi.org/10.3390/su13084421

Academic Editor: João Leitão

Received: 16 March 2021

Accepted: 12 April 2021

Published: 15 April 2021

Publisher's Note: MDPI stays neutral with regard to jurisdictional claims in published maps and institutional affiliations.

Copyright: (c) 2021 by the authors. Licensee MDPI, Basel, Switzerland. This article is an open access article distributed under the terms and conditions of the Creative Commons Attribution (CC BY) license (https:// creativecommons.org/licenses/by/ $4.0 /)$.

\begin{abstract}
Eco-innovation is conducive to reducing the costs and impacts on the environment. Meanwhile, executives play an important role in the whole process of enterprise innovation. However, it is unclear whether and to what extent executives' environmental awareness (EA) affects eco-innovation (EI). Based on the attention-based view, this study discussed the mediating effect of resource flexibility (RF) on the impact of EA on EI and explored the moderating effect of unabsorbed slack resources (USRs). Using surveys collected from 162 Chinese manufacturing firms, we found that (1) EA has a positive impact on EI; (2) RF partially mediates the relationship between EA and eco-management innovation (EMI) and EA and eco-product innovation (EPI); and (3) the effect of EA on EPI weakens with the level of USRs, but the effect of EA on EMI is not affected by the level of USRs. From the perspective of managers' attention, this study not only enriches the main drivers of eco-innovation but also provides a theoretical and practical framework for the promotion and development of eco-innovation in China.
\end{abstract}

Keywords: eco-innovation; executives' environmental awareness; resource flexibility; unabsorbed slack resources; attention-based view

\section{Introduction}

The social environment is increasingly turbulent; however, sacrificing the ecological environment for temporary economic development must be avoided. Under the constraints and challenges of gradually depleted natural resources and serious environmental pollution, eco-innovation can help the environment achieve sustainability [1] and can help society to reduce environmental pollution, which will cause serious harm to China's public health and will lead to low resource efficiency [2]. Furthermore, eco-innovation has always been regarded as the driving force of economic development [3], which can mitigate the financing constraints of enterprises [4]. Therefore, how to promote enterprises' eco-innovation has become a hot topic.

This study focused on the drivers of eco-innovation and its mechanism. Early scholars mainly used new classical and evolutionary economics to investigate the factors affecting eco-innovation at national and industrial levels [5]. Recently, scholars have begun using managerial theory to analyze the factors affecting eco-innovation at the enterprise levels: system [6,7], organization $[6,8]$ and individuals $[9,10]$. Existing literature tends to focus on the external driving factors of enterprises [11], and it is difficult to penetrate into the inner enterprise. Moreover, more research is needed on how micro-factors affect the effective implementation of eco-innovation. To fill this research gap, this study introduced the variable of executives' environmental awareness to study its influence on eco-innovation. In continuous innovation, executives are the core talents and important participants [12,13], influencing the innovation process $[14,15]$. Executives' environmental awareness emphasizes the pursuit of benefits brought by environmental protection actions, on the one hand, and self-responsibility of executives for environmental protection, on the other hand. Whether driven by morality or interests, it objectively promotes the eco-innovation of enterprises. 
However, executives' attention is limited; hence, executives' environmental awareness must be improved, and their attention to eco-innovation must be rationally allocated.

In studying the driving factors of eco-innovation, the path of its influence must be explored. Therefore, this study introduced resource flexibility as a mediating variable. Going deep into the enterprise cannot be separated from the basic role of enterprise resources; therefore, eco-innovation requires appropriate allocation and utilization of resources. Resource flexibility reflects attributes possessed by resources themselves [16], and its essence is to expand the application scope of resources to increase enterprises' right to choose when the environment changes [17]. The characteristic of resource flexibility is that resources can be effectively applied to the development and manufacturing of various products [18], which is also conducive to enterprise eco-innovation. Therefore, to further clarify the process of awareness-resources-innovation, this study introduced resource flexibility as a means for enterprises to use and integrate resources. Through executives' awareness, the applicable scope of resources is influenced, which can change the existing resources to promote eco-innovation. From the perspective of resources, analyzing the way to realize the value of eco-innovation has important practical significance for the rational allocation of enterprise resources.

Moreover, according to the attention-based view, executives' attention will be affected by situated attention [19]. The impact of executives' environmental awareness on ecoinnovation will also be affected by their situations. Meanwhile, unabsorbed slack resources are uncommitted flowing resources of enterprises [20,21], which affect managers' behavior style and attention distribution and then eco-innovation. In this case, this study studied the negative impact of unabsorbed slack resources on the relationship between executives' awareness and eco-innovation.

To sum up, with the continuous enhancement of environmental awareness, enterprises are encouraged to increase the intensity of promoting eco-innovation. As eco-innovation is becoming a competitive factor, research on its main drivers is getting more and more popular. However, the relationship between environmental awareness (EA) and ecoinnovation (EI) has not been thoroughly studied. For this reason, the main purpose of this study was to analyze the relationship between these two variables and answer the following questions: (1) Is there a positive relationship between EA and EI? (2) Does resource flexibility (RF) play a mediating role between them? (3) Do unabsorbed slack resources (USRs) play a moderating role in the relationship between them? To answer the above research questions, this study introduced the attention-based view to explore the relationship among EA, RF and EI. Simultaneously, this paper introduces USRs as a moderating variable and discussed the change of EA under different levels of USRs, which affects eco-innovation behavior.

The theoretical contribution of this paper mainly includes two points: (1) based on the attention-based view (ABV), this study explains the relationship among EA, RF and EI, which enriches the ABV and increases main drivers and influencing paths of EI; and (2) the moderating effect of USRs is verified by ABV-situated attention, whose role depends on the specific manager and enterprise environment, thereby enriching the research on USRs and ABV-situated attention.

In this study, a questionnaire survey was used to collect data to prove the relationship among EA, RF, USRs and EI. This paper has six sections, which are structured as follows. In Section 2, the literature review investigates existing research on attention-based view and eco-innovation to identify the research gaps and hypotheses that were developed. In Section 3, research design and measurement methods are presented. In Section 4, data analysis is conducted in four stages: confirmatory factor analysis, common method bias testing, descriptive statistics and hypotheses testing. In Section 5, discussion is conducted, including general discussion, theoretical implications, practical implications and limitations and future research. In Section 6, conclusions are summarized. 


\section{Theory and Hypotheses}

\subsection{Attention-Based View}

In 1997, Ocasio [19] proposed the concept of attention-based view (ABV), which posits that both executives' cognition and organizational structure limit and affect the problems and solutions they could pay attention to [22,23]. In addition, Ocasio (1997) [19] defined "attention" as the process in which an organization manager allocates a limited time and energy to pay attention, code, explain and focus on questions and answers. The basic concept of enterprise attention is based on the following three basic principles:

1. Focus of attention. What decision-makers do depends on the issues and answers they pay attention to.

2. Situated attention. What problems decision-makers pay attention to and what they do depend on their specific environment or situation. Moreover, the importance of situational factors in explaining their decision-making process is emphasized.

3. Structural distribution of attention. This explains how the company's economic and social structure regulates and guides issues and solutions. It also describes how decision-makers allocate their attention to activities, communication and processes in different situations [19].

Generally speaking, ABV tries to explain how decision-makers allocate their attention to enterprise problems and understanding enterprise behavior and results [24].

$\mathrm{ABV}$ is an important theoretical viewpoint in the research field of organizational behavior and management science, which holds that the attention of enterprise management is an important resource within an organization. Under the assumption of a manager's bounded rationality, a manager's decision depends on where he/she focuses his/her attention. In addition, from the perspective of attention distribution, how to rationally allocate limited attention resources to different aspects in the innovation process is a challenge that enterprises have been facing [19]. Therefore, if enterprises want to conduct eco-innovation better, they must overcome the limitation of managers' attention and focus their attention on the field of eco-innovation. Consequently, this paper discusses the relationship among EA, RF and EI by using ABV.

ABV opens the "black box" of enterprises and emphasizes the importance of situated attention in selectively focusing the attention of decision-makers. Executives' attention is influenced by their situation. Thus, this present study explored the moderating role of USRs in the relationship between EA and EI by using ABV-situated attention.

\subsection{Eco-Innovation}

Fussler and James (1996) first proposed the concept of eco-innovation [25]. Rennings (2000) [5] defined eco-innovation as all measures taken by relevant actors to develop and introduce new ideas, behaviors, products and processes, which will help reduce the environmental burden or achieve the environmental sustainability goals. In addition, he indicated that eco-innovation is an innovation with environmental benefits. On the basis of the development of management innovation theory, eco-innovation has experienced the stage of technological innovation and green innovation [26].

Eco-innovation is different from general innovation. (1) It is an innovation that emphasizes reducing environmental impact, whether it is intentional or not. (2) It is not limited to the innovation of products, processes, marketing methods and organizational methods but also includes the innovation of social dimension [2,3]. (3) Eco-innovation pursues a "win-win" situation between economy and environment [27], that is, it promotes environmental sustainability while improving competitiveness, and finally solves the problem of dual market failure [28]. Research by Zhou et al. (2019) [29] showed that eco-innovation can bring environmental and economic performance, which is an inevitable trend for enterprises to improve their competitiveness and sustainable management under the background of "green economy" [30,31]. However, simultaneously, eco-innovation needs relevant conditions to achieve the expected good performance results [32], and different kinds of eco-innovation have different effects on performance [33]. Ryszko (2016) [34] 
tested whether there is a direct relationship between proactive eco-innovation strategy and enterprise performance. Cai and Li (2018) [27] examined the relationship between eco-innovation and performance; however, the results show that the direct impact of ecoinnovation on economic performance was not significant, which was indirectly realized through the mediating of environmental performance.

Cheng and Shiu (2012) [35] divided eco-innovation into eco-organization innovation, eco-process innovation and eco-product innovation. To further study eco-innovation, in this paper, eco-innovation is divided into two parts: eco-management innovation (EMI) and eco-product innovation (EPI). The former refers to the implementation of various ecological plans, the introduction of ecological learning technology and the establishment of management teams and management systems to deal with ecological problems. The latter refers to the redesign and development of products that use less energy, reduce waste and contain less harmful substances to human health.

\section{Executives and Eco-Innovation}

Eco-innovation often has high risks and uncertainties, and it needs to invest a lot of resources in the short term to generate uncertain long-term returns [36]. Executives play a key role in the generation and implementation of environmental innovation and whose personal image (personality [37], religious beliefs [38], political connections [36] and ability [39]) and situation [40,41] (power and position) have influence on eco-innovation. Arena et al. (2018) [37] proved that CEO hubris positively affects eco-innovation, but its influence degree is affected by organizational slack and the external environment. In addition, the research showed that the CEO's power is related to environmental innovation. When the CEO has a high degree of environmental awareness, empowering the CEO is beneficial to eco-innovation [42], which makes the company design an appropriate monitoring structure [41], but other executives with certain rights will feel that their positions are guaranteed, and as a result, they will not act in the best interests of different stakeholder groups and participate in less corporate social responsibility [40], thus restraining eco-innovation.

Simultaneously, the influence of executives on eco-innovation is affected by their situation. If an executive believes in a certain religion, the doctrine or thought of that religion will inevitably affect his/her personal risk preference, thus affecting his/her willingness for eco-innovation [38]. In China, informal ties are more prominent, and political ties are critical for reducing future political uncertainty and obtaining government support. Therefore, executives with political ties have more risk-taking ability and risk tolerance, which can encourage them to pay more attention to environmental issues and encourage enterprises to conduct more eco-innovation [36].

Based on previous studies, executives are critical for eco-innovation. This paper focuses on the variable of EA, mainly studying the relationship between EA and EI.

\subsection{Executives' Environmental Awareness and Eco-Innovation}

ABV holds that an important resource in an organization is the attention of executives, whose attention is selective, in which they only pay attention to some questions and answers while blocking others [43]. From the point of ABV, the attention of managers is the main reason why enterprises take different actions in adapting to their business environment and developing new products and services [44].

Environmental awareness reflects personal perception and behavior tendency of environmental problems [45], and executives' environmental awareness (EA) is the concrete manifestation of executives' cognition. Gadenne et al. (2009) [10] defined EA as managers' awareness of environmental pollution caused by enterprises and increased business performance by adopting environmental protection behaviors. Managers' attention to the environment is critical for industries related to energy conservation [46]. When executives continuously devote their limited time and attention to issues related to the environment, EA enables them to have keen insight into environmental problems, which helps them realize these problems in time and respond to them [47]. 
EA plays a positive role in eco-innovation. With the shortage of global resources, environmental degradation and pollution, countries all over the world pay more attention to sustainable development. Meanwhile, China's central government attaches great importance to the development of the manufacturing industry, thus the external institutional pressure and social expectations [28] all promote the enhancement of EA. On the one hand, the higher the EA they have, the more they pay attention to the influence of legal pressure and code of ethics. Thus, they will consider social and environmental responsibilities when they gain economic benefits and take the initiative to bring eco-innovation into a strategic height to reduce the harm of corporate behavior to society and the environment [46]. With the enhancement of EA, they are more responsible for eco-innovation and more willing to invest their resources and capabilities in the field of eco-innovation [26]. Environmentoriented executives are more likely to be aware of the potential benefits of government regulations [48]. Gadenne et al. (2009) [10] found that EA has a significant positive impact on the implementation of the environmental management system and environmental protection measures (recycling, emission reduction and consumption reduction), which shows the positive impact of EA on eco-innovation of enterprises. Yin et al. (2019) [13] pointed out that executives with high environmental awareness are more likely to realize the potential benefits of government-regulated incentive measures. Enterprises no longer meet the minimum requirements of environmental supervision, but they actively integrate internal and external green knowledge, promote eco-innovation and obtain government subsidies. Huang et al. (2020) [26] pointed out that executives with strong environmental awareness can use ambidextrous learning to help organizations rationally allocate their resources and capabilities, which is conducive to improving eco-innovation performance.

On the other hand, facing market pressure [46], bounded by extant regulations [28] and considering shareholders' profits, executives who have higher environmental awareness can better identify and grasp the potential opportunities and economic returns brought by eco-innovation, giving more support to this "win-win" behavior. With the improvement of EA, the potential benefits and market opportunities of eco-innovation are easier to be identified. Executives with high environmental awareness regard consumers and suppliers' attention to eco-innovation as market opportunities to integrate internal and external green knowledge, develop green new products needed by consumers and form competitive advantages [13]. Moreover, executives are affected by new innovation policies including innovation incentives [28], which provide positive rewards for those who implement transformation [49]. Executives with higher environmental awareness are more likely to change from moderate innovators to innovation leaders, which is conducive to improving the efficiency level of human management and natural resource development, thus promoting eco-innovation [28]. Chang (2011) [50] pointed out that executives with strong environmental awareness will stimulate enterprises to adopt a proactive environmental strategy, and are more likely to conduct eco-innovation. Thus, we proposed the following hypotheses:

Hypothesis H1a. Executives' environmental awareness is positively related to eco-management innovation.

Hypothesis H1b. Executives' environmental awareness is positively related to eco-product innovation.

\subsection{The Mediating Role of Resource Flexibility}

Sanchez (1995) [16] divided strategic flexibility into resource flexibility (RF) and coordination flexibility. This paper mainly studies $\mathrm{RF}$, which reflects the attributes of organizational resources, including the use range, conversion time and costs [51].

RF plays a mediating role in the relationship between EA and EI. A basic premise of $\mathrm{ABV}$ is the scarcity of attention resources, and different problems in the organization will compete for limited attention [19]. Executives can locate the limited resources of the company [52], and EA emphasizes that executives will allocate limited attention to environmental issues. Moreover, executives influence RF, which depends on their cognition [53]. 
Therefore, EA affects RF, and through it, existing flexible resources can be more easily used for new purposes, thereby expanding the scope of resource use, reducing the cost and difficulty of resource conversion among different purposes, shortening the conversion time and promoting the generation of creative behaviors [54,55]. On the one hand, RF can enhance the technical diversity of internal resources and expand the scope of resource exploration. Therefore, accumulating internal flexible resources can produce new and creative resource combinations, thus realizing innovation [56]. RF broadens the degree of openness to innovation [57]. On the other hand, RF can reduce the response time to dynamic changes and help enterprises redeploy resources well and improve the value of innovative resources [56]. Simultaneously, resource constraints can be overcome by redeploying existing resources or acquiring new resources [58], thereby increasing the introduction of new products [59]. RF ensures matching resource package of target innovation and reduces the time and cost of finding new resources and converting these resources from one use to another [60]. Changing the attributes of enterprise resources through RF allows them to be more conducive to the eco-innovation behavior of enterprises. Thus, we proposed the following hypotheses:

Hypothesis H2a. Resource flexibility mediates the relationship between executives' environmental awareness and eco-management innovation.

Hypothesis H2b. Resource flexibility mediates the relationship between executives' environmental awareness and eco-product innovation.

\subsection{The Moderating Role of Unabsorbed Slack Resources}

Cyert and March (1963) [61] first proposed the concept of unabsorbed slack resources (USRs). In addition, according to the flexibility of slack resources, Sharfman et al. (1988) [62] divided it into two types: absorbed slack resources and USRs. Different types of slack resources have different characteristics [63], USRs are uncommitted flowing resources, such as cash flow [64], which have more flexibility and can be easily recovered or absorbed by the company's technical activities. Meanwhile, absorbed slack resources are resources absorbed into operation as costs, such as excessive management fees, which are beyond the necessary scope for normal operation [64]. This paper mainly studies USRs because USRs are superior to absorbed slack resources in re-integrating resources and seizing potential opportunities [65]. In addition, for eco-innovation, USRs are easier to deploy than absorbed slack resources [66].

USRs play a negative role in moderating the relationship between EA and EI. First, more USRs may encourage managers to pursue their own interests more, instead of acting in accordance with the interests of the organization [67]. USRs are available resources that managers can allocate to any purpose at any time [68]. Resources themselves are static, and the value they create depends on managers' allocation of resources. USRs represent unnecessary payment [69], which will lead managers to pursue more new projects. This rarely translates into value-added innovation. Moreover, these unrecorded investments in these R\&D activities cannot produce more economic benefits. Second, eco-innovation of enterprises is a highly complex and uncertain problem for enterprises. Compared with conventional innovation, eco-innovation has higher uncertainty [70], and enterprises with too many USRs tend to avoid risks, thus inhibiting the motivation of experiments and risks [71]. Therefore, for eco-innovation, a large number of USRs will hinder its development [21]. Finally, managers who think that eco-innovation will bring benefits to enterprises and improve their competitiveness may become lazy and complacent when they have too many USRs [71], thus reducing their awareness of environmental protection and reducing their motivation for eco-innovation. Excessive USRs will lead to corruption and other phenomena, and thus, executives will ignore environmental laws and regulations and reduce their attention to environmental issues, thereby hindering enterprises in the emergence of eco-innovation. ABV posits that USRs will affect the attention paid by 
executives to environmental protection and impede the increase of EA and thus ecoinnovation. Accordingly, we proposed the following hypotheses:

Hypothesis H3a. Unabsorbed slack resources moderate the relationship between executives' environmental awareness and eco-management innovation, such that this relationship is stronger at low levels of unabsorbed slack resources.

Hypothesis H3b. Unabsorbed slack resources moderate the relationship between executives' environmental awareness and eco-product innovation, such that this relationship is stronger at low levels of unabsorbed slack resources.

To sum up, this study discussed the relationship among EA, RF and EI, and explored the moderating effect of USRs. Figure 1 presents the theoretical model of this study.

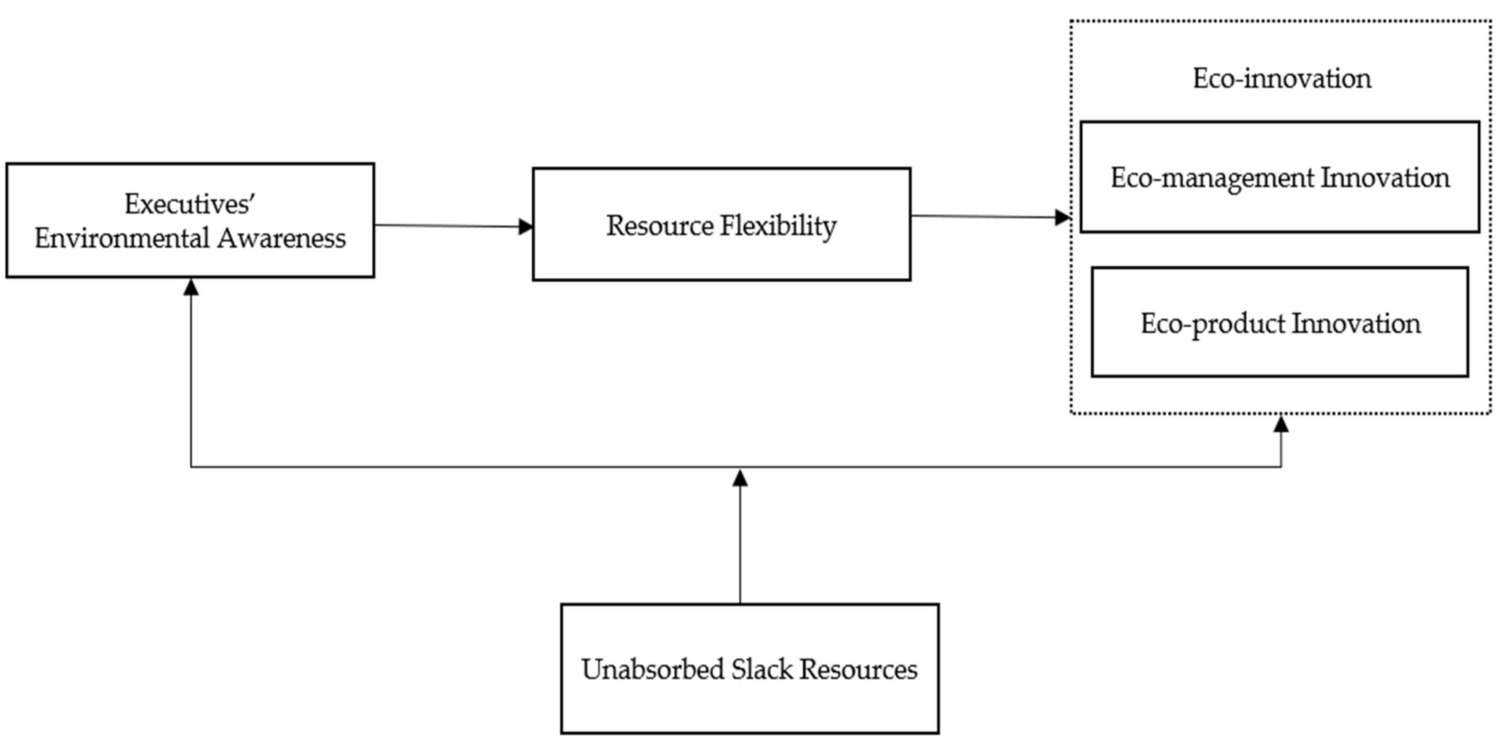

Figure 1. Theoretical model.

\section{Research Design}

\subsection{Sample and Data Selection}

In this paper, a questionnaire survey was used to collect data. Manufacturing enterprises with serious pollution in Beijing, Shanghai, Zhejiang, Hebei, Liaoning, Shanxi and Tianjin were selected as survey objects. Choosing manufacturing enterprises as the investigation object was mainly due to their strong willingness for eco-innovation as the main body of resource consumption and environmental pollution in China [27].

To ensure the validity and reliability of the questionnaire, two professors in the field of innovation and several senior managers of enterprises were invited to delete some ambiguous items. After revision, the questionnaire was pre-tested among several MBA students, and some difficult items were revised. Finally, a formal questionnaire, including 25 questions in total, was formed and issued in two ways: (1) we contacted research companies to collect questionnaires from specific research objects; (2) through the mentor project, we contacted the company executives of the project entrusted party and contacted more through company executives by snowballing.

In this survey, 344 questionnaires were distributed, and 212 responses were received, with a recovery rate of $61.6 \%$. Incomplete questionnaires such as missing items and contradictory questionnaires were eliminated, thus leaving 162 valid questionnaires, with an effective questionnaire rate of $47.1 \%$. In this paper, SPSS 20.0 software (IBM company, Stanford University, USA) was used to analyze the sample data, and the descriptive statistics of the sample are shown in Table 1. 
Table 1. Descriptive statistics.

\begin{tabular}{|c|c|c|c|c|c|}
\hline Gender & Frequency & Percentage & Position & Frequency & Percentage \\
\hline Male & 96 & $59.3 \%$ & Senior manager & 68 & $42 \%$ \\
\hline Female & 66 & $40.7 \%$ & Middle manager & 42 & $25.9 \%$ \\
\hline Seniority & & & Junior manager & 51 & $31.5 \%$ \\
\hline 5 and below & 20 & $12.3 \%$ & Others & 1 & $0.6 \%$ \\
\hline 6 to 10 & 98 & $60.5 \%$ & Type & & \\
\hline 10 and above & 44 & $27.2 \%$ & Food and beverage & 17 & $10.5 \%$ \\
\hline Scale & & & Textile and apparel & 14 & $8.6 \%$ \\
\hline 100 and below & 11 & $6.8 \%$ & Paper and printing & 10 & $6.2 \%$ \\
\hline 101 to 500 & 71 & $43.8 \%$ & $\begin{array}{l}\text { Chemicals and } \\
\text { petrochemicals }\end{array}$ & 20 & $12.3 \%$ \\
\hline 501 to 1000 & 35 & $21.6 \%$ & Rubber and plastics & 10 & $6.2 \%$ \\
\hline 1001 to 2000 & 27 & $16.7 \%$ & $\begin{array}{l}\text { Non-metallic mineral } \\
\text { products }\end{array}$ & 4 & $2.5 \%$ \\
\hline 2000 and above & 18 & $11.1 \%$ & Smelting and pressing & 1 & $0.6 \%$ \\
\hline Nature & & & Metal products & 10 & $6.2 \%$ \\
\hline State-owned enterprise & 35 & $21.6 \%$ & Mechanical and engineering & 42 & $25.9 \%$ \\
\hline Privately enterprise & 93 & $57.4 \%$ & Electronics and electrical & 31 & $19.1 \%$ \\
\hline Foreign enterprise & 21 & $13 \%$ & $\begin{array}{l}\text { Instruments and related } \\
\text { products }\end{array}$ & 2 & $1.2 \%$ \\
\hline Others & 13 & $8 \%$ & Others & 1 & $0.6 \%$ \\
\hline
\end{tabular}

\subsection{Analysis Techniques}

In this study, SPSS 20.0 software was used to analyze the descriptive statistics of the variables, while AMOS 20.0 (IBM company, Stanford University, USA) was used for confirmatory factor analysis. To test the mediating effect and mediating type of resource flexibility, this study used the Baron-Kenny (1986) [72] multiple regression method. Moreover, the main and moderating effects were tested by SPSS 20.0.

\subsection{Measures}

The questionnaire collected ratings using 7-point Likert-type scales ranging from 1 (strongly disagree) to 7 (strongly agree). The scales used in this paper are all from the published literature of foreign authoritative journals; they are widely used by mainstream literature at home and abroad.

Eco-innovation. Based on the research of Cheng et al. (2012) [35], this paper divides eco-innovation into EMI and EPI. We drew on the research design of Chen et al. (2006) [73], Cheng et al. (2012) [35] and Cai et al. (2018) [27] and modified the scale along with the case in this paper, and finally, EMI determined six specific questions, and EPI determined five specific questions.

Executives' environmental awareness. We drew lessons from the research of Gadenne et al. (2009) [10] and Huang et al. (2020) [26]. Then, we modified the scale along with the case in this paper and finally determined six specific questions.

Resource flexibility. We drew on the research designs of Sanchez (1995) [16] and Li et al. (2017) [56] combined with the case in this paper to modify the measurement items and finally determined five specific questions.

Unabsorbed slack resources. We drew lessons from Bourgeois et al. (1981) [20], Liu et al. (2019) [74] and Sun et al. (2020) [75]. We modified the measurement items along with the scenario of this paper to determine three specific questions. 
Control variables. Learning from previous scholars, we selected gender, position, seniority, industry type, scale and nature as control variables. Previous studies have shown that industry type [34], scale [3,76] and nature [27] will affect resource stock and eco-innovation; executives' gender, position and seniority $[37,40]$ will affect awareness and behavior of executives.

\section{Results}

\subsection{Confirmatory Factor Analysis}

Confirmatory factor analysis of the following five variables was conducted using AMOS 20.0: EA, RF, USRs, EMI and EPI. The results in Table 2 show that the model fit of five factors $\left(\chi^{2}=395.79, \mathrm{df}=265, \chi^{2} / \mathrm{df}=1.494, \mathrm{CFI}=0.925, \mathrm{TLI}=0.915, \mathrm{RMSEA}=0.055\right)$ was significantly better than other nested models.

Table 2. Results of confirmatory factor analysis.

\begin{tabular}{clcccccc}
\hline Models & & $\chi^{2}$ & df & $\chi^{2} / \mathbf{d f}$ & RMSEA & CFI & TLI \\
\hline Five factors & EA, RF, USRs, EMI, EPI & 395.79 & 265 & 1.494 & 0.055 & 0.925 & 0.915 \\
Four factors & EA, RF, USRs, EMI+EPI & 462.453 & 269 & 1.719 & 0.067 & 0.889 \\
Three factors & EA, RF+USRs, EMI+EPI & 562.272 & 272 & 2.067 & 0.081 & 0.834 & 0.876 \\
Two factors & EA+RF+USRs, EMI+EPI & 692.509 & 274 & 2.527 & 0.097 & 0.76 & 0.738 \\
One factors & EMI+EPI+EA+RF+USRs & 740.867 & 275 & 2.694 & 0.103 & 0.733 & 0.709 \\
\hline
\end{tabular}

\subsection{Common Method Bias Testing}

Considering that EA, RF, USRs, EMI and EPI may have common method bias (CMB), this paper adopted Harman's single-factor test, which is accepted by most studies, that is, all the items in the questionnaire were analyzed by a non-rotating factor, and the variance contribution rate of the factor with the highest degree of explanation was $37.348 \%$. Therefore, $\mathrm{CMB}$ is not significant in this paper.

\subsection{Descriptive Statistics}

Table 3 presents the descriptive statistics and correlations between all variables. As shown in Table 3, executives' environmental awareness is positively correlated with ecomanagement innovation $(\mathrm{r}=0.680, p<0.010)$ and eco-product innovation $(\mathrm{r}=0.650$, $p<0.010)$, while executives' environmental awareness is positively correlated with resource flexibility $(\mathrm{r}=0.417, p<0.010)$.

\subsection{Hypotheses Testing}

\subsubsection{Main and Mediating Effects}

Using SPSS 20.0, this paper tested the main and mediating effects of the model of the Baron-Kenny (1986) [72] multiple regression method. The hierarchical regression results are shown in Table 4: Model 2 shows that executives' environmental awareness has a significant positive impact on eco-management innovation $(\beta=0.775, p<0.001)$, and Model 5 shows that executives' environmental awareness has a significant positive impact on eco-product innovation ( $\beta=0.582, p<0.001)$. Therefore, H1a and H1b are supported. 
Table 3. Descriptive statistics of the variables.

\begin{tabular}{|c|c|c|c|c|c|c|c|c|c|c|c|}
\hline & Gender & Seniority & Position & Type & Scale & Nature & EMI & EPI & EA & USRs & RF \\
\hline Gender & - & & & & & & & & & & \\
\hline Seniority & -0.078 & - & & & & & & & & & \\
\hline Type & -0.026 & 0.043 & 0.131 & - & & & & & & & \\
\hline Scale & -0.086 & 0.120 & 0.138 & 0.067 & - & & & & & & \\
\hline Nature & 0.094 & 0.040 & 0.058 & -0.084 & -0.106 & - & & & & & \\
\hline EMI & -0.083 & -0.032 & -0.140 & -0.040 & 0.012 & $-0.165^{*}$ & $(0.841)$ & & & & \\
\hline EA & $-0.260^{* *}$ & -0.023 & -0.169 * & -0.049 & 0.053 & -0.109 & $0.680^{* *}$ & $0.613^{* *}$ & $(0.816)$ & & \\
\hline USRs & -0.153 & -0.072 & -0.008 & 0.011 & 0.124 & -0.028 & $0.458^{* *}$ & $0.405^{* *}$ & $0.401^{* *}$ & $(0.821)$ & \\
\hline RF & -0.093 & -0.06 & -0.104 & -0.057 & -0.048 & -0.143 & $0.578^{* *}$ & 0.452 ** & $0.493^{* *}$ & $0.505^{* *}$ & (0.849) \\
\hline Mean & 1.407 & 3.148 & 1.963 & 6.407 & 2.815 & 2.074 & 5.652 & 5.893 & 5.888 & 5.638 & 5.425 \\
\hline SD & 0.493 & 0.613 & 0.984 & 3.347 & 1.138 & 0.816 & 0.739 & 0.665 & 0.660 & 0.889 & 0.844 \\
\hline
\end{tabular}


Table 4. Result of main and mediating effects.

\begin{tabular}{|c|c|c|c|c|c|c|c|c|}
\hline \multirow{2}{*}{ Variable } & \multicolumn{3}{|c|}{ EMI } & \multicolumn{3}{|c|}{ EPI } & \multicolumn{2}{|c|}{ RF } \\
\hline & M1 & M2 & M3 & M4 & M5 & M6 & M7 & M8 \\
\hline \multicolumn{9}{|l|}{ Control } \\
\hline Gender & -0.068 & 0.167 & 0.150 & $-0.332 * *$ & -0.156 & -0.166 & -0.127 & 0.064 \\
\hline Seniority & -0.065 & -0.010 & 0.003 & -0.036 & 0.005 & 0.013 & -0.092 & -0.047 \\
\hline Position & -0.098 & -0.029 & -0.026 & -0.023 & 0.028 & 0.030 & -0.068 & -0.013 \\
\hline Type & -0.008 & -0.001 & 0.001 & -0.009 & -0.004 & -0.003 & -0.014 & -0.008 \\
\hline Scale & 0.012 & -0.013 & 0.002 & 0.029 & 0.010 & 0.019 & -0.035 & -0.055 \\
\hline Nature & -0.138 & -0.090 & -0.062 & -0.115 & -0.079 & -0.062 & -0.143 & -0.105 \\
\hline \multicolumn{9}{|c|}{$\begin{array}{l}\text { Independent } \\
\text { variable }\end{array}$} \\
\hline EA & & $0.775^{* * *}$ & $0.606^{* * *}$ & & $0.582^{* * *}$ & $0.483^{* * *}$ & & $0.627^{* * *}$ \\
\hline \multicolumn{9}{|l|}{$\begin{array}{l}\text { Mediator } \\
\text { variable }\end{array}$} \\
\hline RF & & & $0.270^{* * *}$ & & & $0.157^{* *}$ & & \\
\hline $\mathrm{R}^{2}$ & 0.050 & 0.484 & 0.554 & 0.098 & 0.399 & 0.429 & 0.044 & 0.262 \\
\hline$\Delta \mathrm{R}^{2}$ & - & $0.434^{* * *}$ & $0.070 * * *$ & - & $0.301^{* * *}$ & $0.030^{* * *}$ & - & $0.218^{* * *}$ \\
\hline $\mathrm{F}$ & 1.371 & $20.634^{* * * *}$ & $23.760^{* * *}$ & 2.808 * & $14.626^{* * *}$ & $14.349^{* * *}$ & 1.196 & $7.797^{* * *}$ \\
\hline
\end{tabular}

Results of the mediating effect are shown in Table 4. Drawing lessons from the three steps of the mediating effect test proposed by Baron (1986) [72], this study undertook the following steps. The first step was to conduct the regression of the dependent variable to the independent variable. Models 2 and 5 show that EA has a significant impact on EMI $(\beta=0.775, p<0.001)$ and EPI $(\beta=0.582, p<0.001)$. In the second step, the regression of mediator variables to independent variables was conducted. Model 8 shows that EA ( $\beta=0.627, p<0.001$ ) has a significant impact on RF. The third step was to do the regression of the dependent variable to the independent variable and mediator variable. First, in EMI, Model 3 shows that RF has a significant impact on EMI $(\beta=0.270, p<0.001)$. At this time, EA ( $\beta=0.606, p<0.001)$ still has a significant impact on EMI. Second, in terms of EPI, Model 6 shows that RF has a significant impact on EPI $(\beta=0.157, p<0.010)$. At this time, EA $(\beta=0.483, p<0.001)$ still has a significant impact on EPI. Comprehensive Models 2 , 3 and 8 show that RF plays a partial mediating role in the relationship between EA and EMI. Comprehensive Models 5, 6 and 8 show that RF plays a partial mediating role in the relationship between EA and EPI. $\mathrm{H} 2 \mathrm{a}$ and $\mathrm{H} 2 \mathrm{~b}$ are supported.

\subsubsection{Moderating Effect}

SPSS 20.0 was used to test the moderating effect, and the results are shown in Table 5 . Model 4 shows that USRs have no moderating effect on the positive relationship between EA and EMI $(\beta=-0.073, p>0.1)$. Model 8 shows that USRs play a significant negative role in moderating the positive relationship between EA and EPI $(\beta=-0.208, p<0,010)$. Therefore, H3a is not supported, and H3b is supported. 
Table 5. The result of moderating effects.

\begin{tabular}{|c|c|c|c|c|c|c|c|c|}
\hline \multirow{2}{*}{ Variable } & \multicolumn{4}{|c|}{ EMI } & \multicolumn{4}{|c|}{ EPI } \\
\hline & M1 & M2 & M3 & M4 & M5 & M6 & M7 & M8 \\
\hline Gender & -0.068 & 0.167 & 0.189 & 0.188 * & -0.332 & -0.156 & -0.141 & -0.144 \\
\hline Seniority & -0.065 & -0.010 & 0.012 & 0.001 & -0.036 & 0.005 & 0.021 & -0.011 \\
\hline Position & -0.098 & -0.029 & -0.036 & -0.038 & -0.023 & 0.028 & 0.023 & 0.017 \\
\hline Type & -0.008 & -0.001 & -0.002 & -0.001 & -0.009 & -0.004 & -0.005 & -0.001 \\
\hline Scale & 0.012 & -0.013 & -0.029 & -0.037 & 0.029 & 0.010 & -0.001 & -0.025 \\
\hline Nature & -0.138 & -0.090 & -0.097 & -0.098 & -0.115 & -0.079 & -0.084 & -0.085 \\
\hline EA & & $0.775^{* * *}$ & $0.671^{* * *}$ & $1.061^{* *}$ & & $0.582 * * *$ & $0.509 * * *$ & $1.617^{* * *}$ \\
\hline USRs & & & $0.199 * * *$ & 0.625 & & & $0.139^{* *}$ & $1.346^{* *}$ \\
\hline EA*USRs & & & & -0.073 & & & & $-0.208^{* *}$ \\
\hline $\mathrm{R}^{2}$ & 0.050 & 0.484 & 0.531 & 0.534 & 0.098 & 0.399 & 0.428 & 0.458 \\
\hline$\Delta \mathrm{R}^{2}$ & - & $0.434^{* * *}$ & $0.023^{* * *}$ & $0.003^{* * *}$ & - & $0.301^{* * *}$ & $0.029^{* * *}$ & $0.030^{* * *}$ \\
\hline $\mathrm{F}$ & 1.3711 & $20.634^{* * *}$ & $21.659 * * *$ & $19.364^{* * *}$ & $2.808 *$ & $14.626^{* * *}$ & $14.289^{* * *}$ & $14.283^{* * *}$ \\
\hline
\end{tabular}

In order to further test the moderating effect of USRs in this relationship, this study drew the moderating effect diagram for analysis (shown in Figure 2). Figure 2 shows that the more USRs, the weaker the positive relationship between EA and EPI. That is, compared with enterprises with fewer USRs, enterprises with more USRs are less likely to improve their EPI.

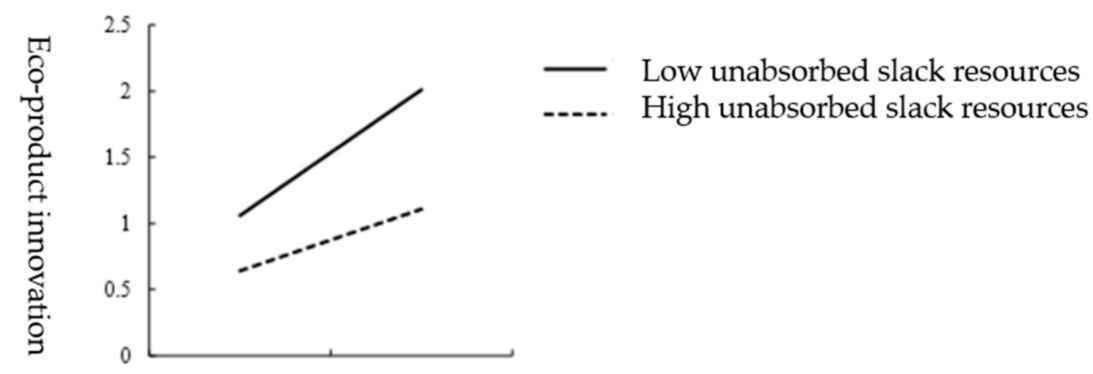

Executives' environmental awareness

Figure 2. Moderating effect of unabsorbed slack resources.

\section{Discussion}

\subsection{General Discussion}

5.1.1. Executives' Environmental Awareness and Eco-Innovation

Executives' environmental awareness has a positive impact on eco-innovation, in particular, on both eco-management innovation and also eco-product innovation. The results are consistent with previous research [37,41], emphasizing the positive effect of executives on eco-innovation. On the one hand, the improvement of executives' environmental awareness has enhanced their emphasis on environmental protection laws and measures. Moreover, it stimulated eco-management innovation steps, such as, actively collecting and sharing information about eco-innovation and adopting new environmental management systems and methods. Simultaneously, executives' environmental awareness stimulates eco-product innovation: developing products with low energy consumption, easy recycling and degradability and minimizing the production of products that waste resources. On the other hand, the improvement of executives' environmental awareness elicits their attention to the benefits of environmental protection, economic measures and competitiveness 
of enterprises, thus promoting eco-management innovation and eco-product innovation. Therefore, companies should have high environmental awareness, especially in terms of increasing the economic and environmental benefits of enterprises and improving their eco-innovation.

\subsubsection{The Mediating Role of Resource Flexibility}

The results reveal the partial mediating role of resource flexibility between executives' environmental awareness and eco-management innovation, which also plays a partial mediating role between executives' environmental awareness and eco-product innovation; its mediating role is even greater. Previous studies have proved the influence of executives on resource flexibility $[51,53]$, which was also proved in this study, emphasizing the influence of executives' environmental awareness on resource flexibility. Moreover, it is consistent with previous studies, emphasizing the positive effect of resource flexibility on enterprise innovation [57,77-79]. Executives' environmental awareness has a positive impact on eco-management innovation and eco-product innovation. However, the implementation of awareness- innovation needs resources for support. Resource flexibility is an effective way to help enterprises overcome inertia, which can effectively change the use scope of resources or recombine them, make up for the shortage of existing resources, quickly provide resources and capabilities needed for eco-innovation and reduce the impact of market changes. Thus, resource flexibility indeed plays an important role in promoting enterprises' eco-innovation. Therefore, executives' environmental awareness can change enterprise resource attributes through resource flexibility and expand the scope of resource use. Moreover, it can make existing flexible resources easier to use for eco-innovation and reduce the cost, difficulty and time of resource conversion, which is more conducive to the generation of enterprise's eco-innovation behavior. All in all, through resource flexibility, enterprises can continuously tap the potential of resources and improve eco-innovation by changing and combining their effectiveness to achieve new goals.

\subsubsection{The Moderating Role of Unabsorbed Slack Resources}

The empirical results of unabsorbed slack resources and enterprise innovation have been mixed; there are three relationships among them: positive, negative and U-shaped. The results of this study are inconsistent with one of the results of previous studies, emphasizing that unabsorbed slack resources play a negative moderating role in the relationship between executives' environmental awareness and eco-product innovation.

Unabsorbed slack resources do not play a significant role in moderating the relationship between executives' environmental awareness and eco-management innovation. A possible explanation for this is that compared with eco-product innovation, ecomanagement innovation is more about the ability and commitment to implement ecomanagement innovation with eco-innovation [35], and its R\&D cost is lower. Therefore, the impact of executives' environmental awareness on eco-management innovation is less constrained by resources; another explanation is that eco-management innovation is more symbolic than substantive. Moreover, managers have a relatively more direct influence on eco-management innovation, whereas external resources and the environment have less influence on it. Therefore, the negative influence of unabsorbed slack resources on their relationship is limited. Therefore, unabsorbed slack resources have no significant moderating effect on the impact of executives' environmental awareness on eco-management innovation.

Unabsorbed slack resources play a negative role in moderating the relationship between executives' environmental awareness and eco-product innovation. The role is mainly to improve the environmental impact of existing ecological products or to develop new ecological products [35], which is highly dependent on resources and has certain development risks. On the one hand, with more unabsorbed slack resources, executives tend to be lazier and avoid risks, thus causing them to remain in the status quo that is not conducive to the enhancement of their environmental protection awareness and inhibiting the creation of 
eco-product innovation behavior. On the other hand, executives will reduce their awareness of environmental protection due to complacency and neglect the benefits brought by environmental protection measures. Moreover, they may even ignore environmental protection laws and regulations, thus resisting eco-product innovation from the inside. In addition, unabsorbed slack resources may also cause random investment, but it does not play a substantial role in the innovation of new products. Therefore, the high level of unabsorbed slack resources is unfavorable to the positive relationship between executives' environmental awareness and eco-product innovation.

\subsection{Theoretical Implications}

The following are this study's theoretical implications:

1. Based on ABV, this study emphasized the importance of executives' attention as a scarce resource of enterprises, enriched the path of awareness-resources-innovation, studied the moderating role of unabsorbed slack resources based on the situated attention and enriched the research perspective of ABV.

2. Previous studies on eco-innovation have focused on the driving effect of internal and external macro-environment, ignoring the micro-factor of executives. Based on the ABV, this study aids in the better understanding that executives' environmental awareness promotes the starting mechanism of enterprise eco-innovation.

3. Executive awareness is an important research topic in micro-psychology; however, in the past, related studies have mainly focused on the upper echelon theory and strategic choice theory [80]. Moreover, studies often used demographic characteristics [81] that executives can directly observe to infer and represent executives' cognition. In contrast, this paper chooses a unique perspective of $\mathrm{ABV}$ for direct measurement of executives' cognition and pays attention to the influence of executives' environmental awareness on enterprise's eco-innovation. Therefore, the research on executives' environmental awareness can effectively make up for the lack of research.

4. In this paper, the mediating role of resource flexibility is explained by ABV. Moreover, this study explored the influence path and internal mechanism of executives' environmental awareness and eco-innovation, which opens the "black box" of the mechanism between them that can help people deeply understand the mechanism of executives' environmental awareness. Further, this study emphasized the key role of managers in managing and allocating resources in the pursuit of corporate goals and the significance of resource flexibility for enterprise eco-innovation.

5. Research on unabsorbed slack resources is seldom from the perspective of organizational decision-makers. The use of resources depends on managers. In this study, unabsorbed slack resources were used as a situation that can affect executives' attention. Moreover, this study explored its moderating effect on the relationship between executives' environmental awareness and eco-innovation, which enriches research on unabsorbed slack resources.

\subsection{Practical Implications}

1. Different sections may have different propensities for eco-innovation [1]. This study took manufacturing as a research sample because manufacturing is the foundation of China's real economy. Meanwhile, it is necessary to conduct high-quality development, which makes the whole manufacturing industry more inclined to ecoinnovation strategy than other industries. Therefore, the Chinese manufacturing industry attaches importance to eco-innovation. In addition, the upgrading of other industries can learn from the experience of manufacturing transformation, which promotes the sustainability of the whole society.

2. Eco-innovation is the main driver for the transformation and upgrading of the manufacturing industry. Consequently, the state should strengthen the policy management of eco-innovation. The current policy can be conducted through active promotion and passive enforcement $[2,28]$. (1) The initiative and investment of green and digital 
transformation should be promoted; meanwhile, necessary technical support should be given to innovative enterprises. Moreover, EMS certification should be encouraged, such as EMAS or ISO14001. (2) The cost of violating environmental protection regulations should be increased. Simultaneously, tax can be used to restrain eco-innovation behavior and thus promote eco-innovation performance.

3. China's manufacturing industry is facing various environmental problems, including environmental deterioration and ecological destruction. Compared with other positions, managers, who play an important role in the confirmation of environmental problems and the implementation of enterprises' environmental strategies, can lead the company's other employees to conduct education or training related to environmental protection [33]. Managers' awareness is a unique resource of enterprise, which can increase or decrease enterprise value and have a significant impact on the acquisition and maintenance of an enterprise's competitive advantage. Therefore, enterprises should pay attention to the cultivation of managers' environmental awareness. Meanwhile, managers should pay more attention to the dynamics and trends of national environmental protection policies and strategies. The more managers think that environmental problems are business opportunities, the stronger their environmental awareness is, which will likely cause enterprises to implement eco-innovation that improves their sustainability and competitiveness. In addition, enterprises should improve executives' environmental awareness for enterprises changing from passive innovation under external pressure to active innovation and thus promote the voluntary combination of eco-innovation activities.

4. The manufacturing industry, as a pillar industry in China, is related to the economic lifeline of the country. However, the Chinese manufacturing industry has the realistic problem of "big but not strong". Moreover, the shortage of resources hinders the development of the manufacturing industry. Therefore, if an enterprise wants to conduct eco-innovation, it should not only improve the executives' environmental awareness but also make resources gather, integrate and transform in innovation instead of only possessing resources. Meanwhile, enterprises should make full use of internal and external resources, improve their resource flexibility and strengthen coordination and communication among various departments. In addition, enterprises should solve the problem of low resource utilization rate through resource flexibility, thus enhancing their innovation ability. In a highly turbulent environment, only resources are flexible enough to create and maintain core competitiveness.

5. Unabsorbed slack resources can stabilize the core activities of the company and cultivate the strategic behavior of creating value. Simultaneously, they may be used to destroy efficiency and value [69]. However, the foothold always lies in how to use it. Managers should consider the different functions of unabsorbed slack resources and deploy them differently to make use of the importance of resources and prevent them from becoming the fuse of innovation restrain. Therefore, managers should actively manage the resources in the organization that exceed the requirements for daily operation.

\subsection{Limitations and Future Research}

Although this study followed the logic of scientific research, it still has some limitations. First, the research samples may be limited in number and geography. These conclusions have not been confirmed in more areas. Further studies are required to enhance the popularization of the research results in the future.

In addition, this paper mainly studies the impact of executives' environmental awareness on eco-innovation, which is discussed from a single perspective within the organization. This study lacks the integration and comparison of the driving factors of ecoinnovation from multiple perspectives of internal organizational structure and external institutional pressure, which are the future research direction. 


\section{Conclusions}

The prosperity of the manufacturing industry is the foundation for China to become a powerful country. The high-quality development of the manufacturing industry is the top priority of China's high-quality economic development. Meanwhile, eco-innovation is critical to improve the quality of the manufacturing industry. Therefore, it is essential to drive eco-innovation for the development of our country.

From the perspective of attention, as the decision-makers of enterprises, what executives pay more attention to will determine which activities the enterprises will devote themselves to. The more attention executives pay to environmental protection, the higher executives' environmental awareness they have, thus promoting the eco-innovation of enterprises. Based on ABV, this study analyzed the way to realize the value of eco-innovation. Using the data of the Chinese manufacturing industry, this study drew the following conclusions: (1) executives' environmental awareness is positively related to eco-innovation; (2) resource flexibility mediates the relationship between executives' environmental awareness and eco-innovation; and (3) unabsorbed slack resources negatively moderate the relationship between executives' environmental awareness and eco-innovation. This study provides favorable guidance for enhancing managers' awareness and rationally integrating and using enterprise resources.

This study mainly studied the impact of executives on eco-innovation; in the future, the research can be from multiple perspectives. Moreover, this paper focuses on the drivers of eco-innovation, and its consequences are not involved. In addition, the relationship between eco-innovation and enterprise performance (economic and environmental performance) is ambiguous. Therefore, future studies can make a more systematic analysis of eco-innovation, combining its drivers and consequences. Measurement scales, construct items, measurement model and factor loading are shown in Appendix A.

Author Contributions: Conceptualized the research design, Y.S.; methodology, H.S.; software, H.S.; validation, H.S.; formal analysis, H.S.; resources, Y.S.; data curation, H.S.; writing-original draft preparation, H.S.; writing-review and editing, Y.S.; visualization, Y.S.; supervision, Y.S.; project administration, Y.S.; funding acquisition, Y.S. Both authors have read and agreed to the published version of the manuscript.

Funding: This research was supported by the National Social Science Foundation of China [Grant number 18BGL083].

Institutional Review Board Statement: Not applicable.

Informed Consent Statement: Not applicable.

Data Availability Statement: Not applicable.

Conflicts of Interest: The authors declare no conflict of interest. 


\section{Appendix A}

Table A1. Measurement scales and construct items.

\section{Items}

Eco-management innovation

1. Our unit management often adopts new environmental management systems or methods.

2. Our unit management often collects and shares the latest news of eco-innovation.

3. Our unit management often actively conduct and participates in various eco-innovation activities.

4. Our unit management often invests a lot of R\&D in eco-innovation.

5. Our unit management often communicates with employees about eco-innovation information.

6. Our unit management often exchanges experiences among various departments involved in eco-innovation.

\section{Eco-product innovation}

1. Our unit often emphasizes developing new products through new technologies to simplify their construction and packaging

2. Our unit often emphasizes developing new products through new technologies to easily decompose their raw materials.

3. Our unit often emphasizes developing new products through new technologies to use natural materials.

4. Our unit often emphasizes developing recyclable products through new technologies.

5. Our unit often emphasizes developing low energy consumption products through new technologies.

Executives' environmental awareness

1. Our unit management believes that environmental protection will improve the sales revenue of enterprises

2. Our unit management believes that environmental protection will improve the production efficiency of enterprise.

3. Our unit management believes that environmental protection will improve the competitiveness of enterprises.

4. Our unit management attaches great importance to environmental protection.

5. Our unit management believes that it is critical for the survival of enterprises to take on environmental responsibility

6. Our unit management attaches great importance to the adverse impact of enterprises' activities on the natural environment.

Resource flexibility

1. The effective scope of the use of our unit resources is relatively wide.

2. The difficulty and cost of switching the use of our unit resources to an alternative one are low.

3. The time of switching the use of our unit resources to an alternative one are low.

4. The degree of sharing the same resources among all departments within our unit is high.

5. The extent of the same resources used in developing, producing, and selling different products is high

Unabsorbed slack resources

1. Our company has enough discretionary cash surplus

2. Our company has a pool of funds that can be available for market expansion

3. Our company can get the bank loan we needed 
Table A2. Measurement model and factor loading.

\begin{tabular}{|c|c|c|c|c|c|}
\hline Construct & Items & Factor Loading & Cronbach's $\alpha$ & CR & AVE \\
\hline \multirow[t]{6}{*}{ Executives' environmental awareness } & EA1 & 0.814 & 0.816 & 0.903 & 0.608 \\
\hline & EA2 & 0.766 & & & \\
\hline & EA3 & 0.786 & & & \\
\hline & EA4 & 0.736 & & & \\
\hline & EA5 & 0.757 & & & \\
\hline & EA6 & 0.817 & & & \\
\hline \multirow[t]{5}{*}{ Resource flexibility } & RF1 & 0.887 & 0.849 & 0.898 & 0.638 \\
\hline & RF2 & 0.716 & & & \\
\hline & RF3 & 0.768 & & & \\
\hline & RF4 & 0.776 & & & \\
\hline & RF5 & 0.835 & & & \\
\hline \multirow[t]{3}{*}{ Unabsorbed slack resource } & USRs1 & 0.814 & 0.821 & 0.840 & 0.637 \\
\hline & USRs2 & 0.774 & & & \\
\hline & USRs3 & 0.805 & & & \\
\hline \multirow[t]{6}{*}{ Eco-management innovation } & EMI1 & 0.719 & 0.841 & 0.903 & 0.609 \\
\hline & EMI2 & 0.847 & & & \\
\hline & EMI3 & 0.772 & & & \\
\hline & EMI4 & 0.756 & & & \\
\hline & EMI5 & 0.858 & & & \\
\hline & EMI6 & 0.718 & & & \\
\hline \multirow[t]{5}{*}{ Eco-product innovation } & EPI1 & 0.774 & 0.818 & 0.889 & 0.615 \\
\hline & EPI2 & 0.816 & & & \\
\hline & EPI3 & 0.765 & & & \\
\hline & EPI4 & 0.741 & & & \\
\hline & EPI5 & 0.822 & & & \\
\hline
\end{tabular}

\section{References}

1. Alos-Simo, L.; Verdu-Jover, A.J.; Gomez-Gras, J.M. Does activity sector matter for the relationship between eco-innovation and performance? Implications for cleaner production. J. Clean. Prod. 2020, 263, 121544. [CrossRef]

2. Cai, W.G.; Zhou, X.L. On the drivers of eco-innovation: Empirical evidence from China. J. Clean. Prod. 2014, 79, 239-248. [CrossRef]

3. Arranz, N.; Arroyabe, M.F.; Molina-García, A.; Arroyabe, J. Incentives and inhibiting factors of eco-innovation in the Spanish firms. J. Clean. Prod. 2019, 220, 167-176. [CrossRef]

4. Zhang, Y.; Xing, C.; Wang, Y. Does green innovation mitigate financing constraints? Evidence from China's private enterprises. J. Clean. Prod. 2020, 264, 121698. [CrossRef]

5. Rennings, K. Redefining innovation-Eco-innovation research and the contribution from ecological economics. Ecol. Econ. 2000, 32, 319-332. [CrossRef]

6. Horbach, J.; Rammer, C.; Rennings, K. Determinants of eco-innovations by type of environmental impact-The role of regulatory push/pull, technology push and market pull. Ecol. Econ. 2012, 78, 112-122. [CrossRef]

7. Berrone, P.; Fosfuri, A.; Gelabert, L.; Gomez-Mejia, R.L. Necessity as the mother of 'green' inventions: Institutional pressures and environmental innovations. Strateg. Manag. J. 2013, 34, 891-909. [CrossRef]

8. Peng, X.; Liu, Y. Behind eco-innovation: Managerial environmental awareness and external resource acquisition. J. Clean. Prod. 2016, 139, 347-360. [CrossRef]

9. Hart, S.L. A natural resource-based view of the firm. Acad. Manag. Rev. 1995, 20, 986-1014. [CrossRef]

10. Gadenne, D.L.; Kennedy, J.; McKeiver, C. An Empirical Study of Environmental Awareness and Practices in Smes. J. Bus. Ethics 2009, 84, 45-63. [CrossRef] 
11. Bossle, M.B.; Barcellos, M.D.d.; Vieira, L.M.; Sauvée, L. The drivers for adoption of eco-innovation. J. Clean. Prod. 2016, 113, 861-872. [CrossRef]

12. Latan, H.; Jabbour, C.J.C.; de Sousa Jabbour, A.B.L.; Wamba, S.F.; Shahbaz, M. Effects of environmental strategy, environmental uncertainty and top management's commitment on corporate environmental performance: The role of environmental management accounting. J. Clean. Prod. 2018, 180, 297-306. [CrossRef]

13. Yin, S.; Li, B.; Zhang, X.; Zhang, M. How to Improve the Quality and Speed of Green New Product Development? Processes 2019, 7, 443. [CrossRef]

14. Joseph, J.; Wilson, A.J. The growth of the firm: An attention-based view. Strateg. Manag. J. 2018, 39, 1779-1800. [CrossRef]

15. Fagerlin, W.P. Top managers' communication efforts as response to tensions in product innovation: An attention-based view. Balt. J. Manag. 2020, 16, 21-45. [CrossRef]

16. Sanchez, R. Strategic flexibility in product competition. Strateg. Manag. J. 1995, 16, 135-159. [CrossRef]

17. Chod, J.; Markakis, M.G.; Trichakis, N. On the Learning Benefits of Resource Flexibility. Manag. Sci. 2021. [CrossRef]

18. Zheng, K.; Zhou, F.W. Technological capability, strategic flexibility, and product innovation. Strateg. Manag. J. 2010, 31, 547-561.

19. Ocasio, W. Towards an attention-based view of the firm. Strateg. Manag. J. 1997, 18, 187-206. [CrossRef]

20. Bourgeois, L.J. On the Measurement of Organizational Slack. Acad. Manag. Rev. 1981, 6, 29-39. [CrossRef]

21. Tabesh, P.; Vera, D.; Keller, R.T. Unabsorbed slack resource deployment and exploratory and exploitative innovation: How much does CEO expertise matter? J. Bus. Res. 2019, 94, 65-80. [CrossRef]

22. Kleinknecht, R.; Haq, H.U.; Muller, A.R.; Kraan, K.O. An attention-based view of short-termism: The effects of organizational structure-ScienceDirect. Eur. Manag. J. 2020, 38, 244-254. [CrossRef]

23. Holm, D.B.; Drogendijk, R.; Haq, H.U. An attention-based view on managing information processing channels in organizations. Scand. J. Manag. 2020, 36, 101106. [CrossRef]

24. Jeremy, G. Do Boards of Directors Influence Corporate Sustainable Development? An Attention-Based Analysis. Bus. Strategy Environ. 2018, 27, 742-756.

25. Fussler, C.; James, P. Driving Eco-Innovation: A Breakthrough Discipline for Innovation and Sustainability; Pitman: London, UK, 1996.

26. Huang, S.-Z.; Lu, J.-y.; Chau, K.Y.; Zeng, H.-L. Influence of Ambidextrous Learning on Eco-Innovation Performance of Startups: Moderating Effect of Top Management's Environmental Awareness. Front. Psychol. 2020, 11, 1976. [CrossRef] [PubMed]

27. Cai, W.; Li, G. The drivers of eco-innovation and its impact on performance: Evidence from China. J. Clean. Prod. 2018, 176, 110-118. [CrossRef]

28. Costa, J. Carrots or Sticks: Which Policies Matter the Most in Sustainable Resource Management? Resources 2021, 10, 12. [CrossRef]

29. Zhou, Y.; Shu, C.; Jiang, W.; Gao, S. Green management, firm innovations, and environmental turbulence. Bus. Strategy Environ. 2019, 28, 567-581. [CrossRef]

30. Liu, Z.; Li, X.; Peng, X.; Lee, S. Green or nongreen innovation? Different strategic preferences among subsidized enterprises with different ownership types. J. Clean. Prod. 2019, 245, 118786. [CrossRef]

31. Santos, D.F.L.; Rezende, M.D.V.; Basso, L.F.C. Eco-innovation and business performance in emerging and developed economies. J. Clean. Prod. 2019, 237, 117674. [CrossRef]

32. Eng, D.; Lai, K.H.; Zhu, Q. Eco-innovation and its role for performance improvement among Chinese small and medium-sized manufacturing enterprises. Int. J. Prod. Econ. 2021, 231, 107869.

33. Long, X.; Chen, Y.; Du, J.; Oh, K.; Yan, J. The effect of environmental innovation behavior on economic and environmental performance of 182 Chinese firms. J. Clean. Prod. 2017, 166, 1274-1282. [CrossRef]

34. Ryszko, A. Proactive Environmental Strategy, Technological Eco-Innovation and Firm Performance-Case of Poland. Sustainability 2016, 8, 156. [CrossRef]

35. Cheng, C.C.; Shiu, E.C. Validation of a proposed instrument for measuring eco-innovation: An implementation perspective. Technovation 2012, 32, 329-344. [CrossRef]

36. Min Huang, M.L.; Liao, Z. Do politically connected CEOs promote Chinese listed industrial firms' green innovation? The mediating role of external governance environments. J. Clean. Prod. 2021, 278, 123634. [CrossRef]

37. Arena, C.; Michelon, G.; Trojanowski, G. Big Egos Can Be Green: A Study of CEO Hubris and Environmental Innovation. Br. J. Manag. 2018, 29, 316-336. [CrossRef]

38. Liao, Z.; Dong, J.; Weng, C.; Shen, C. CEOs' religious beliefs and the environmental innovation of private enterprises: The moderating role of political ties. Corp. Soc. Responsib. Environ. Manag. 2019, 26, 972-980. [CrossRef]

39. García-Sánchez, I.-M.; Aibar-Guzmán, B.; Aibar-Guzmán, C.; Azevedo, T.-C. CEO ability and sustainability disclosures: The mediating effect of corporate social responsibility performance. Corp. Soc. Responsib. Environ. Manag. 2020, 27, 1565-1577. [CrossRef]

40. Harper, J.; Sun, L. CEO power and corporate social responsibility. Am. J. Bus. 2019, 34, 93-115. [CrossRef]

41. Aibar-Guzmán, B.; Frías-Aceituno, J.-V.; Xi, C. Is It Necessary to Centralize Power in the CEO to Ensure Environmental Innovation? Adm. Sci. 2021, 11, 27. [CrossRef]

42. Sheikh, S. The impact of market competition on the relation between CEO power and firm innovation. J. Multinatl. Financ. Manag. 2018, 44, 36-50. [CrossRef]

43. Ocasio, W.; Joseph, J. An Attention-Based Theory of Strategy Formulation: Linking Micro- and Macroperspectives in Strategy Processes. Adv. Strateg. Manag. 2005, 22, 39-61. 
44. Sakhdari, K.; Burgers, J.H. The moderating role of entrepreneurial management in the relationship between absorptive capacity and corporate entrepreneurship: An attention-based view. Int. Entrep. Manag. J. 2018, 14, 927-950. [CrossRef]

45. Fransson, N.; Gärling, T. Environmental Concern: Conceptual Definitions, Measurement Methods, and Research Findings. J. Environ. Psychol. 1999, 19, 369-382. [CrossRef]

46. Zhang, B.; Wang, Z.; Lai, K. Mediating effect of managers' environmental concern: Bridge between external pressures and firms' practices of energy conservation in China. J. Environ. Psychol. 2015, 43, 203-215. [CrossRef]

47. Tseng, M.L.; Wang, R.; Chiu, A.S.F.; Geng, Y.; Lin, Y.H. Improving performance of green innovation practices under uncertainty. J. Clean. Prod. 2013, 40,71-82. [CrossRef]

48. Huang, S.Z.; Chau, K.Y.; Chien, F.; Shen, H. The Impact of Startups' Dual Learning on Their Green Innovation Capability: The Effects of Business Executives' Environmental Awareness and Environmental Regulations. Sustainability 2020, 12, 6526. [CrossRef]

49. Stefan, B.; Raimund, B. Sustainable Resource Management: Global Trends, Visions and Policies; Routledge: Abingdon, UK, 2017.

50. Chang, C.H. The Influence of Corporate Environmental Ethics on Competitive Advantage: The Mediation Role of Green Innovation. J. Bus. Ethics 2011, 104, 361-370. [CrossRef]

51. Herrmann, S.N.P. CEO personality, strategic flexibility, and firm performance: The case of the Indian business process outsourcing industry. Acad. Manag. J. 2010, 53, 1050-1073.

52. Barnett, M.L. An Attention-Based View of Real Options Reasoning. Acad. Manag. Rev. 2008, 3, 606-628. [CrossRef]

53. Fernandez-Perez, V.; Garcia-Morales, V.J.; Cabeza Pulles, D. Entrepreneurial decision-making, external social networks and strategic flexibility: The role of CEOs' cognition. Eur. Manag. J. 2016, 34, 296-309. [CrossRef]

54. Han, C.; Zhang, S. Multiple strategic orientations and strategic flexibility in product innovation. Eur. Res. Manag. Bus. Econ. 2021, 27, 100136. [CrossRef]

55. Ren, Q.; Xu, Y.; Zhou, R.; Liu, J. Can CEO's Humble Leadership Behavior Really Improve Enterprise Performance and Sustainability? A Case Study of Chinese Start-Up Companies. Sustainability 2020, 12, 3168. [CrossRef]

56. Li, Y.; Li, P.P.; Wang, H.; Ma, Y. How Do Resource Structuring and Strategic Flexibility Interact to Shape Radical Innovation? J. Prod. Innov. Manag. 2017, 34, 471-491. [CrossRef]

57. Farnese, M.L.; Fida, R.; Livi, S. Reflexivity and flexibility: Complementary routes to innovation? J. Manag. Organ. 2016, 22, 404-419. [CrossRef]

58. Kim, B.; Kim, E.; Foss, N.J. Balancing absorptive capacity and inbound open innovation for sustained innovative performance: An attention-based view. Eur. Manag. J. 2016, 34, 80-90. [CrossRef]

59. Meng, M.; Lei, J.; Jiao, J.; Tao, Q. How does strategic flexibility affect bricolage: The moderating role of environmental turbulence. PLoS ONE 2020, 15, e0238030. [CrossRef] [PubMed]

60. Kamasak, R.; James, S.R.; Yavuz, M. The interplay of corporate social responsibility and corporate political activity in emerging markets: The role of strategic flexibility in non-market strategies. Bus. Ethics Eur. Rev. 2019, 28, 305-320. [CrossRef]

61. Cyert, R.M.; March, J.G. A Behavioral Theory of the Firm; Prentice-Hall/Pearson Education: Englewood Cliffs, NJ, USA, 1963.

62. Sharfman, M.P.; Wolf, G.; Chase, R.B.; Tansik, D.A. Antecedents of Organizational Slack. Acad. Manag. Rev. 1988, 13, 601-614. [CrossRef]

63. Tan, J.; Peng, M.W. Organizational slack and firm performance during economic transitions: Two studies from an emerging economy. Strateg. Manag. J. 2003, 24, 1249-1263. [CrossRef]

64. Kim, K.; Ok, C.; Kang, S.C.; Bae, J.; Kwon, K. High-performance work systems with internal and external contingencies: The moderating roles of organizational slack and industry instability. Hum. Resour. Manag. 2020. [CrossRef]

65. $\mathrm{Wu}, \mathrm{H} . ; \mathrm{Hu}, \mathrm{S}$. The impact of synergy effect between government subsidies and slack resources on green technology innovation. J. Clean. Prod. 2020, 274, 122682. [CrossRef]

66. Wang, Y.; Guo, B.; Yin, Y. Open innovation search in manufacturing firms: The role of organizational slack and absorptive capacity. J. Knowl. Manag. 2017, 21, 656-674. [CrossRef]

67. Antle, R.; Fellingham, J. Resource Rationing and Organizational Slack in a Two-Period Model. J. Account. Res. 1990, $28,1$. [CrossRef]

68. Lu, L.H.; Huang, Y.F. Manufacturing strategy, organizational slack, and the formation of interfirm linkages. Chin. Manag. Stud. 2019, 13, 70-92. [CrossRef]

69. Vanacker, T.; Collewaert, V.; Zahra, S.A. Slack resources, firm performance, and the institutional context: Evidence from privately held European firms. Strateg. Manag. J. 2017, 38, 1305-1326. [CrossRef]

70. Cainelli, G.; De Marchi, V.; Grandinetti, R. Does the development of environmental innovation require different resources? Evidence from Spanish manufacturing firms. J. Clean. Prod. 2015, 94, 211-220. [CrossRef]

71. Kim, H.; Kim, H.; Lee, P.M. Ownership Structure and the Relationship Between Financial Slack and R\&D Investments: Evidence from Korean Firms. Organ. Sci. 2008, 19, 404-418.

72. Baron, R.M.; Kenny, D.A. The moderator-mediator variable distinction in social psychological research: Conceptual, strategic, and statistical considerations. J. Personal. Soc. Psychol. 1986, 51, 1173-1182. [CrossRef]

73. Chen, Y.S.; Lai, S.B.; Wen, C.T. The Influence of Green Innovation Performance on Corporate Advantage in Taiwan. J. Bus. Ethics 2006, 67, 331-339. [CrossRef]

74. Liu, L.; Yu, B.; Wu, W. The Formation and Effects of Exploitative Dynamic Capabilities and Explorative Dynamic Capabilities: An Empirical Study. Sustainability 2019, 11, 2581. [CrossRef] 
75. Sun, Y.; Du, S.; Ding, Y. The Relationship between Slack Resources, Resource Bricolage, and Entrepreneurial Opportunity Identification-Based on Resource Opportunity Perspective. Sustainability 2020, 12, 1199. [CrossRef]

76. Aragon-Correa, J.A.; Hurtado-Torres, N.; Sharma, S.; Garcia-Morales, V.J. Environmental strategy and performance in small firms: A resource-based perspective. J. Environ. Manag. 2008, 86, 88-103. [CrossRef] [PubMed]

77. Wei, Z.; Yi, Y.; Guo, H. Organizational Learning Ambidexterity, Strategic Flexibility, and New Product Development. J. Prod. Innov. Manag. 2014, 31, 832-847. [CrossRef]

78. Yang, J.; Zhang, F.; Jiang, X.; Sun, W. Strategic flexibility, green management, and firm competitiveness in an emerging economy. Technol. Forecast. Soc. Chang. 2015, 101, 347-356. [CrossRef]

79. Gulati, N.R. Is Slack Good or Bad for Innovation? Acad. Manag. J. 1996, 39, 1245-1264.

80. Child, J. Strategic Choice in the Analysis of Action, Structure, Organizations and Environment: Retrospect and Prospect. Organ. Stud. 1997, 18, 43-76. [CrossRef]

81. Buyl, T.; Boone, C.; Matthyssens, P. Upper echelons research and managerial cognition. Strateg. Organ. 2011, 9, 240-246. [CrossRef] 